\title{
WELLNESS PROCESS ACCORDING TO LIFESTYLE AS A SOCIAL CHALLENGE ON THE EXAMPLE OF SELECTED UNIVERSITY STUDENTS
}

\author{
[Wellness proces podle životního stylu jako společenská výzva na prríkladu \\ vybraných vysokoškoláků]
}

\author{
Dagmar Svobodová ${ }^{1}$ \\ ${ }^{1}$ Slezská univerzita v Opavě, Obchodně podnikatelská fakulta, Univerzitní nám. 1934/3, 73340 Karviná \\ Email: svobodova@opf.slu.cz
}

\begin{abstract}
The aim of the article is to frame the wellness process of selected university students of the Silesian University in Opava, School of Business Administration in Karviná for the academic year 2019/2020 according to their lifestyle. The theoretical basis of the article is the wellness concept of Travis and Ryan with energy sources combined with active and passive lifestyles. The research methodology implements a quantitative approach to framework analysis in a research study. From the point of view of the SWOT analysis, the results of the study interpret the frameworks of the wellness lifestyle of selected university students according to gender. They present the framing of the wellness process as feedback on the progress in the sustainability of the wellness lifestyle of selected university students as a future social challenge.
\end{abstract}

Keywords: framing, lifestyle, university students, wellness process.

JEL classification: Z13

Received: 24.3.2021; Reviewed: 5.5.2021; 20.5.2021; Accepted: 3.11.2021

\section{Úvod}

Současné výzvy reflektují aktuální situaci moderní společnosti ve vztahu k pandemii COVID19. Jednou z nejaktuálnějších společenských výzev je změna konzumního životního stylu. $\mathrm{S}$ tím souvisí možnost využívat wellness proces $\mathrm{k}$ aktivizaci a $\mathrm{k}$ formování udržitelnějšího lidského života. V této souvislosti je cílem článku zarámovat wellness proces vysokoškoláků Slezské univerzity v Opavě, Obchodně podnikatelské fakulty (SU OPF) v Karviné podle typu životního stylu. Dopady životního stylu na rámec welness procesu vysokoškoláků nahlížíme ze dvou hledisek. Za prvé, zda a jak ovlivňují wellness energetické zdroje rámování wellness procesu vysokoškoláků podle pohlaví a za druhé, které psychologické faktory jako vnitřní a které sociální faktory jako vnější životní proměnné se na rámování wellness životního stylu vysokoškoláků podílejí.

Teoretický základ př́ispěvku tvoří wellness koncept v pojetí Travise a Ryanové (2004) propojený s rámcem aktivního životního stylu podle Bronase, Hannanové a Leona (2019) a pasivniho životního stylu podle Giddense (2013). V článku kombinujeme wellness proces s psychologickými a sociálními faktory, které ovlivňují podle Kubátové (2016) životní styl každého jedince. Základní výzkumný přístup aplikovaný v článku je kvantitativní. Výzkumná studie formou rámcové analýzy vyhodnocuje a interpretuje empirická data, která jsou získaná dotazníkovým výzkumem s vybranými vysokoškoláky SU OPF v Karviné jako respondenty.

S odvoláním na implementací wellness energetických zdrojů, z nichž šest je psychologických a šest sociálnich podle wellness konceptu Travise a Ryanové (2004) do rámců aktivního životního stylu podle Bronase, Hannanové a Leona (2019) a pasivního životního stylu podle Giddense (2013) předpokládáme rozdilný př́stup vybraných vysokoškoláků SU OPF v Karviné 
podle jejich pohlaví k rámování wellness procesu. Podle Stroheckera (2013) je hypotéza o rozdílném př́stupu $\mathrm{k}$ rámováni wellness procesu podle pohlaví respondentů operacionalizována do dvanácti motivačních výroků, na které v dotazníkovém výzkumu odpovídali vysokoškoláci ze dvou výběrových podsouborů. Rámováním wellness procesu tak přistupují k zpětné vazbě o směřování k udržitelnosti svého životního stylu.

\section{Wellness koncept s rámci životního stylu}

Wellness koncept v pojetí Travise a Ryanové (2004) chápe jedince jako živý otevřený organismus, který přijímá energii z vnějšího prostředí, energii zpracovává a do okolí energii vrací. Je-li proud energie vyrovnaný, jedinec se cítí dobře. Vyskytne-li se však při vstupu, výstupu nebo transformaci energie překážka, jedinec se cítí prázdný, zmatený a stresovaný. Efektivní proudění energie je ve wellness konceptu zásadní, protože z negativních dopadů energetické nerovnováhy vyplývají různé zdravotní problémy. Strohecker (2013) v konceptu wellness vymezuje dvanáct energetických zdrojů, mezi které řadí Odpovědnost, Dýchání, Vnímání, Výživu, Pohyb, Pocity, Myšlenky, Hru a práci, Komunikaci, Intimitu, Smysluplnost a Transcendenci.

Odpovědnost objevuje individuální potřeby jedince a hledá přímé cesty $\mathrm{k}$ jejich naplnění. Jedinec si uvědomuje, že je odborníkem na sebe sama, vyjadřuje sebe sama, své myšlenky a emoce způsobem, kterým okolí sděluje, kdo je, co potřebuje a co umí. Neztrácí naději ani v těžkých situacích, protože si uvědomuje odpovědnost za své propojení s okolním prostředím.

Dýchání jako základní životní funkce potřebuje kyslík, který je pro lidský organismus nezbytný. Kyslík každého jedince drží při životě, a protože proudí automaticky, vlastnímu dýchání věnuje jedinec málo pozornosti. Nedostatek kyslíku bývá způsoben vnějšími vlivy (vyšší nadmořská výška, nedostatečné větrání přelidněných místností). K nedostatečnému dýchání vede špatné držení těla a svalová tenze způsobená stresem, vztekem nebo smutkem. Tělesný rozvoj napovídá, jak důležité je dýchání pro komunikaci, práci a hru jedince.

Vnímání potřebuje jedinec k poznávání světa prostřednictvím smyslů, mezi které patři chut', čich, sluch, hmat a zrak. Smyslové vnímání chápeme nejen jako vnímání elektromagnetických vln (teplo, světlo, zvuk), ale i jako vnímání emoční a spirituální energie, kterou jedinci předávají své pocity. Zpracování smyslových vjemů ovlivňuje, jak jedinec komunikuje s okolím, jak dobře odvádí svou práci a jak se cítí, proto potřebuje umět se smyslovými vjemy účinně zacházet.

Výživa ovlivňuje lidské zdraví, přestože se někteří jedinci špatně stravují, trpí nadváhou a zdravotními potížemi. Špatnou výživu lze připsat životnímu stylu, který vyhledává okamžité uspokojení a přehlíží dlouhodobé následky. Jedinci chybí informace, jak se správně stravovat, převládá stres a špatná kvalita potravin. Výživa v podobě jídla se pro jedince stává jedním ze způsobů, jak si ulevit od psychické zátěže.

Pohyb je základním projevem lidského života. Omezení pohybu je známkou onemocnění, protože tělo se bez pohybu stává náchylnější $\mathrm{k}$ depresím a infekcím. Blokování pohybu představuje zánik lidského organismu. Pohybový rozvoj je klíčovou životní proměnnou wellness procesu. Zdravý jedinec v pohybu setrvává a pohybem reaguje na změny prostředí. Č́m více se jedinec pohybuje, tím více generuje novou energii.

Pocity jsou známky emocí, které mohou být příjemné, nepř́ijemné, pochopené, nepochopené nebo potlačované. Jedná-li jedinec emocionálně, jeho reakce upřednostňuje prožívání. Pocity 
jsou z biologické podstaty součástí lidského života, proto je třeba se s nimi naučit přiměřeně zacházet.

Myšlenky sídlí v lidském mozku. Po náročně psychické práci se jedinec cítí unavený, protože myšlení spotřebovává jeho mentální energii. $Z$ uvedeného důvodu je třeba mít na paměti nejen myšlenkové zdroje, ale i dopady, které mají myšlenky na psychické a fyzické zdraví.

Hra a práce jsou kategorie, do kterých lze rozdělit lidské aktivity. Hra je spontánní aktivita, která není podřízena výkonu nebo cíli, protože je radostná a kreativní spojená s pocitem plynutí. Práce je synonymem úkolů, cílů a odpovědnosti. V současnosti hru v lidském životě nahradily únikové aktivity zábavního průmyslu, který rozptyluje jedince od povinností, ale nepřináší stejné výhody jako práce. Cílem je pochopení podstaty hry a její schopnosti vrátit rovnováhu a inspiraci do života, který je zatížený životní a pracovní odpovědností.

Komunikace je komplexní proces sdělení obsahu od vysílače k přijímači, ve kterém se jedná o vnitřní a vnější verbální komunikaci. Žádné verbální sdělení není přenášeno izolovaně od neverbální komponenty (tón hlasu, výraz obličeje, postoj, zvolené oblečení). Neverbálními signály dává vysílač přijímači najevo nejen, co mu chce sdělit, ale předává rovněž informace o sobě sama. Mezi wellness energetickými zdroji je komunikace proces, kde je nutné přijmout sebe sama, aby bylo možné komunikovat s ostatními, přijímat a přetvářet energii.

Intimitu lze chápat jako dimenzi důvěry a hloubku vztahu mezi lidmi, která má podobu přátelství, rodinných a pracovních vztahů až po vztah s celoživotním partnerem. Uvedené vztahy jsou složité, protože až 70 \% vztahových problémů nelze řešit jednoduše. Rozhodující je způsob, jak se k vztahovým problémům jedinec postaví. Na tomto př́stupu lze formovat důvěrný intimní vztah. Respekt k druhým, přátelství a uznání jsou cestou k pochopení, že kvalita vztahů s ostatními má přímou vazbu na celkovou kvalitu života.

Smysluplnost je jedinečnou lidskou potřebou. Odpovědi na otázky: Kdo jsem? Kam mírím? Co chci? Kde je pravda? na vědomé či nevědomé úrovni jsou základem lidského konání. Rozjímání nad těmito otázkami může přidat každodenním činnostem, které jedinec vykonává, hlubší rozměr a život se tak stává motivovanější.

Transcendence je plná bdělost a zanícení jedince v přítomném okamžiku. Do transcendence lze zařadit vrcholné zážitky a okamžiky plynutí, stav v being in the zone, víru a spiritualitu jako spojení s něčím, co jedince přesahuje.

Energetické zdroje podle Stroheckera (2013) můžeme ve wellness konceptu kombinovat jak s vnitřními, tak s vnějšimi životními proměnnými podle Kubátové (2016), která životní styl charakterizuje jako kvalitativní souvislost psychologických a sociálních faktorů ovlivňujících způsob života podle toho, jak jedinec smysl života chápe a jak význam života interpretuje. Jedná se o konzistentní životní způsob, kde jsou jednotlivé části ve vzájemném souladu a mají společnou jednotící linii s podstatnými činnostmi, vztahy a zvyklostmi specifického typu životního stylu konkrétního jedince. Životní styl v pojetí Kubátové (2016) lze jako sociologickou kategorii rámovat podle aktivního a pasivního typu. Podle Bronase, Hannanové a Leona (2019) je aktivní životní styl důležitý faktor ovlivňující zdraví jedince. V současnosti se pod vlivem negativních dopadů moderní společnosti na životní prostředí dostává do popředí snaha žít aktivně, což zahrnuje životní rytmus, pohybový režim, sportovní aktivity a péči o celkovou tělesnou kulturu osobnosti. Podle Giddense (2013) stojí pasivní životní styl na 
konzumní hromadné spotřebě různého zboží, která sice v masovém měřítku př̌ekovává třídní rozdíly, přestože jsou umocněny vlivem různého vkusu jedinců.

Rámování je podle Majorové (2018) zasazení životního stylu jako sociologické kategorie do konstelace různých individuálních a kontextuálních podmínek. Individuální rámování probíhá osobním nastavením do kontextu podmínek, ve kterých se život jedince odehrává a rámuje tak individuální pohled na záležitosti osobního životního stylu. Kontextuální rámování si lze představit jako změnu nastavení a pohyb od jednoho rámce $\mathrm{k}$ druhému na ose od pasivních (-) k (+) aktivním modelům. Schémata rámců vypadají jako otevřená kniha, kde každá př́ímka představuje jiné pochopení smyslu života a interpretaci jeho významu. Na změně úhlu pohledu jedince k rámování reality životního stylu se podílí zpětná vazba.

\section{Metodologie rámcové analýzy a specifikace empirických dat}

Výzkumným problémem je $\mathrm{v}$ našem př́padě vliv wellness energetických zdrojů na rámování wellness procesu vybraných vysokoškoláků SU OPF v Karviné podle pohlaví. Výběrový soubor respondentů tvoří celkem 185 (100,0 \%) vysokoškoláků, kteří si v akademickém roce 2019/2020 zaregistrovali na SU OPF v Karviné volitelné předměty Profesní poradenství, Kariérové poradenstvi a Komunikačni dovednosti. Výběrový soubor 185 respondenti je konstruovaný podle Hancocka, Stapletonové a Muellera (2018) prostým záměrným výběrem a rozdělený na dva výběrové podsoubory. První výběrový podsoubor tvoří 66 (100\%) budoucích bakalářŭ, z nichž je 51 (77,3 \%) žen a 15 (22,7 \%) mužů. Druhý výběrový podsoubor tvoří 119 (100 \%) budoucích inženýrů, z nichž je 91 žen (76,5 \%) a $28(23,5$ \%) mužů. (Tabulka 1)

Tabulka 1: Výběrové podsoubory vysokoškoláků SU OPF 2019/2020

\begin{tabular}{|l|l|l|}
\hline Pohlaví budoucích bakalářů & $\mathbf{6 6}$ & $\mathbf{1 0 0 . 0} \%$ \\
\hline Ženy & 51 & $77,3 \%$ \\
\hline Muži & 15 & $22,7 \%$ \\
\hline Pohlaví budoucích inženýrů & $\mathbf{1 1 9}$ & $\mathbf{1 0 0 . 0} \%$ \\
\hline Ženy & 91 & 76,5 \\
\hline Muži & 28 & 23,5 \\
\hline
\end{tabular}

Zdroj: Informační systém Slezské univerzity. [online]. 27. srpen 2020 [vid. 27. srpen 2020]. Dostupné z: https://www.slu.cz/slu/cz/issu

Specifikace empirických dat je provedena podle Hancocka, Stapletonové a Muellera (2018) pomocí kvantitativního výzkumného přístupu. V našem př́padě výzkumná studie slouží k rozvoji wellness životních stylů vybraných vysokoškoláků, které posilují jejich př́istup $\mathrm{k}$ rámování wellness procesu a jsou udržitelné. Výzkumná studie je napsaná tak, aby bylo zřejmé, že vybraní vysokoškoláci byli motivovaní při rámování wellness procesů k implementaci wellness energetických zdrojů jako životních faktori̊ podle wellness konceptu Travise a Ryanové (2004) do aktivního nebo pasivního životního stylu. Z důvodu interaktivní výuky Profesniho poradenství, Kariérového poradenství a Komunikačnich dovedností na SU OPF v Karviné v akademickém roce 2019/2020 je výzkumná studie ve formě rámcové analýzy, kterou zpracováváme vyhodnocením získaných empirických dat. V rámci výzkumné studie aplikujeme pro sběr empirických dat dotazování, které realizujeme dotazníkovým výzkumem.

Našim výzkumným cílem bylo získat odpovědi vybraných vysokoškoláků ze dvou výběrových podsouborů na základní výzkumnou otázku: Jak ovlivňují wellness energetické zdroje rámování jejich wellness procesů? V souvislosti s implementací psychologických jako vnitřnich a sociálních jako vnějších životních faktorů podle wellness konceptu Travise a Ryanové (2004) do rámců aktivního životního stylu podle Bronase, Hannanové a Leona (2019) a pasivního životního stylu podle Giddense (2013) ověřjeme hypotézu o rozdilném př́stupu vybraných vysokoškolákủ SU OPF k rámování wellness procesủ podle pohlaví. 
V pojetí Stroheckera (2013) je hypotéza o rozdílném př́stupu vybraných vysokoškoláků SU OPF $\mathrm{k}$ rámování wellness procesů podle pohlaví operacionalizovaná do dvanácti wellness energetických zdrojů, přičemž každý obsahuje tři alternativy motivačních výroků. Skrze klasický škálový dotazník vybraní vysokoškoláci SU OPF prezentovali odpovědi volbou určité alternativy motivačního výroku. Své názory vyjadřovali mírou osobní preference podle škály 1 (nikdy) - 4 (vždy), na kolik jsou pro ně alternativy motivačních výroků k budoucí implementaci wellness energetických zdrojů podle Stroheckera (2013) pravdivé. (Tabulka 2)

Tabulka 2: Dotazník k implementaci wellness energetických zdrojů

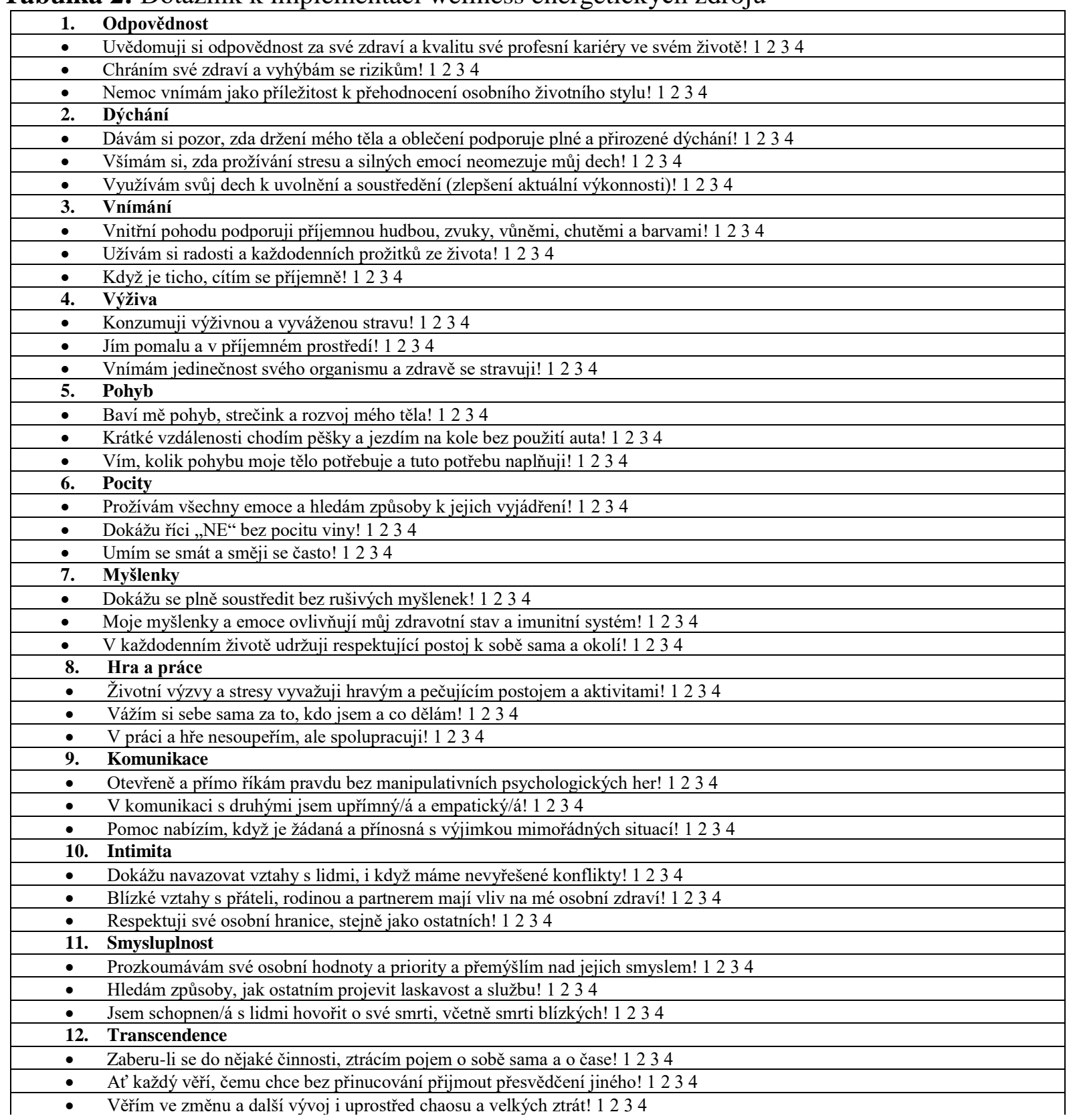

Zdroj: STROHECKER, J., 2013. 12 dimensions of wellness. An invitation to Wellnes inventory certification training [online]. 21. april 2020 [vid. 21. april 2020]. Dostupné z: http://www.wellpeople.com/Wellness_Dimensions.aspx\#Sec1 
Pro výpočet úrovně pravdivosti alternativ motivačních výroků vybraných vysokoškoláků SU OPF 2019/2020 podle pohlaví aplikujeme aritmetický průměr $(x)$ jako součet všech hodnot vydělený jejich počtem.

$x=\left(x_{1}+x_{2}+x_{3}+\ldots+x_{n}\right) / n$

Našim úkolem je srovnat postavení wellness energetických zdrojů v pojetí Stroheckera (2013) $\mathrm{v}$ rámcích wellness procesu vybraných vysokoškoláků podle pohlaví. Variantou $\mathrm{k}$ interpretování wellness procesu obou výběrových podsouborů vysokoškoláků SU OPF 2019/2020 jsou výpočty založené na diferencích podle pořadí sledovaných hodnot wellness energetických zdrojů mezi ženami a muži.

$d_{i}=x_{r i}-y_{r i}$

Které wellness energetické zdroje maji nejvýznamnějši vliv na rámování wellness procesů vysokoškoláků z výběrových podsouborů podle pohlavi? Nejvýznamnější vliv v rámci wellness procesu výběrového podsouboru bakalářů sledujeme mezi ženami $\mathrm{v}$ jejich lepším př́istupu k odpovědnosti, aktivnímu pohybu a smysluplnosti, včetně vnímání. Shoda mezi oběma pohlavími panuje v př́padě dýchání a výživy. Podstatný rozdíl lze spatřovat mezi muži v lepší komunikaci. (Tabulka 3)

Tabulka 3: Wellness energetické zdroje bakalářů SU OPF 2019/2020 podle pohlaví

\begin{tabular}{|c|l|l|l|l|l|}
\hline Bakaláři & Ženy & $\mathbf{X r i}_{\mathbf{r i}}$ & Muži & $\mathbf{y} \mathbf{r i}$ & $d_{i}=x_{r i}-y_{r i}$ \\
\hline 1. Odpovědnost & 3,3 & 4. & 2,6 & 9. & -5 \\
\hline 2. Dýchání & 2,5 & 11. & 2,3 & 11. & 0 \\
\hline 3. Vnímání & 3,2 & 5. & 2,8 & 7. & -2 \\
\hline 4. Výživa & 2,2 & 12. & 1,9 & 12. & 0 \\
\hline 5. Pohyb & 3,6 & 1. & 2,9 & 6. & -5 \\
\hline 6. Pocity & 2,7 & 10. & 2,5 & 10. & 0 \\
\hline 7. Myšlenky & 3,4 & 3. & 3,5 & 1. & 2 \\
\hline 8. Hra a práce & 2,8 & 9. & 2,7 & 8. & 1 \\
\hline 9. Komunikace & 2,9 & 8. & 3,4 & 2. & 6 \\
\hline 10. Intimita & 3,1 & 6. & 3,3 & 3. & 3 \\
\hline 11. Smysluplnost & 3,5 & 2. & 3,1 & 5. & -3 \\
\hline 12. Transcendence & 3,0 & 7. & 3,2 & 4. & 3 \\
\hline
\end{tabular}

Zdroj: vlastní zpracování

Nejvýznamnější vliv v rámci wellness procesu výběrového podsouboru inženýrů spočívají v lepším př́stupu žen $\mathrm{k}$ intimitě a vnímání. Shoda mezi oběma pohlavími panuje $\mathrm{v}$ př́padě dýchání a komunikace. Podstatný rozdíl lze spatřovat v lepším př́istupu mužů k odpovědnosti, pohybu a transcendenci. (Tabulka 4) 
Tabulka 4: Wellness energetické zdroje inženýrů SU OPF 2019/2020 podle pohlaví

\begin{tabular}{|l|l|l|l|l|l|}
\hline Inženýři & Ženy & $\mathbf{x}_{\mathbf{r i}}$ & Muži & $\mathbf{y}_{\mathbf{r i}}$ & $d_{i}=x_{r i}-y_{r i}$ \\
\hline 1. Odpovědnost & 2,9 & 6. & 2,8 & 4. & 2 \\
\hline 2. Dýchání & 2,0 & 12. & 1,9 & 12. & 0 \\
\hline 3. Vnímání & 3,2 & 3. & 2,5 & 7. & -4 \\
\hline 4. Výživa & 2,4 & 11. & 2,2 & 10. & 1 \\
\hline 5. Pohyb & 2,6 & 9. & 2,7 & 5. & 4 \\
\hline 6. Pocity & 2,5 & 10. & 2,3 & 9. & 1 \\
\hline 7. Myšlenky & 2,8 & 7. & 2,4 & 8. & -1 \\
\hline 8. Hra a práce & 2,7 & 8. & 2,6 & 6. & 2 \\
\hline 9. Komunikace & 3,4 & 1. & 3,8 & 1. & 0 \\
\hline 10. Intimita & 3,3 & 2. & 2,1 & 11. & 9 \\
\hline 11. Smysluplnost & 3,1 & 4. & 2,9 & 3. & 1 \\
\hline 12. Transcendence & 3,0 & 5. & 3,1 & 2. & 3 \\
\hline
\end{tabular}

Zdroj: vlastní zpracování

Jak silná je prímá závislost v působení wellnes energetických zdrojů v rámcích wellness procesu na obě pohlaví vybraných vysokoškoláků? Závislost v působení wellness energetických zdrojů v rámcích wellness procesu na obě pohlaví chápeme jako souvislost pořadových znaků, které lze měřit pomocí ordinální korelace. K měření ordinální korelace používáme Spearmanưv korelační koeficient $\left(r_{s}\right)$ jako neparametrickou metodu. (Tabulka 5)

$r_{s}=1-\frac{6 \sum_{i=1}^{n} d_{i}^{2}}{n\left(n^{2}-1\right)}$,

Tabulka 5: Hodnoty pro výpočet Spearmanových korelačních koeficientů podle pohlaví

\begin{tabular}{|c|c|c|c|c|c|}
\hline Wellness energetické zdroje & Ženy (Bc.) & $\mathbf{X}_{\mathbf{r i}}$ & Ženy (Ing.) & $\mathbf{y}_{\mathbf{r i}}$ & $d_{i}=x_{r i}-y_{r i}$ \\
\hline 1. Odpovědnost & 3,3 & 4. & 2,9 & 6. & -2 \\
\hline 2. Dýchání & 2,5 & 11. & 2,0 & 12. & -1 \\
\hline 3. Vnímání & 3,2 & 5. & 3,2 & 3. & 2 \\
\hline 4. Výživa & 2,2 & 12. & 2,4 & 11. & 1 \\
\hline 5. Pohyb & 3,6 & 1. & 2,6 & 9. & -8 \\
\hline 6. Pocity & 2,7 & 10. & 2,5 & 10. & 0 \\
\hline 7. Myšlenky & 3,4 & 3. & 2,8 & 7. & -4 \\
\hline 8. Hra a práce & 2,8 & 9. & 2,7 & 8. & 1 \\
\hline 9. Komunikace & 2,9 & 8. & 3,4 & 1. & 7 \\
\hline 10. Intimita & 3,1 & 6. & 3,3 & 2. & -4 \\
\hline 11. Smysluplnost & 3,5 & 2. & 3,1 & 4. & -2 \\
\hline 12. Transcendence & 3,0 & 7. & 3,0 & 5. & 2 \\
\hline Wellness energetické zdroje & Muži (Bc.) & $\mathbf{x}_{\mathbf{r i}}$ & Muži (Ing.) & $\mathbf{y}_{\mathbf{r i}}$ & $d_{i}=x_{r i}-y_{r i}$ \\
\hline 1. Odpovědnost & 2,6 & 9. & 2,8 & 4. & 5 \\
\hline 2. Dýchání & 2,3 & 11. & 1,9 & 12. & -1 \\
\hline 3. Vnímání & 2,8 & 7. & 2,5 & 7. & 0 \\
\hline 4. Výživa & 1,9 & 12. & 2,2 & 10. & 2 \\
\hline 5. Pohyb & 2,9 & 6. & 2,7 & 5. & 1 \\
\hline 6. Pocity & 2,5 & 10. & 2,3 & 9. & 1 \\
\hline 7. Myšlenky & 3,5 & 1. & 2,4 & 8. & -7 \\
\hline 8. Hra a práce & 2,7 & 8. & 2,6 & 6. & 2 \\
\hline 9. Komunikace & 3,4 & 2. & 3,8 & 1. & 1 \\
\hline 10. Intimita & 3,3 & 3. & 2,1 & 11. & -8 \\
\hline 11. Smysluplnost & 3,1 & 5. & 2,9 & 3. & 2 \\
\hline 12. Transcendence & 3,2 & 4. & 3,1 & 2. & 2 \\
\hline
\end{tabular}

Zdroj: vlastní zpracování 
Spearmanův korelační koeficient měření závislosti působení wellness energetických zdrojů v rámci wellness procesu žen dosahuje hodnoty $\mathrm{r}_{\mathrm{s}}=0,776$.

Spearmanův korelační koeficient měření závislosti působení wellness energetických zdrojů v rámci wellness procesu mužů dosahuje hodnoty $r_{s}=0,997$.

Čím blíže je hodnota Spearmanova korelačního koeficientu k extrémním hodnotám, tím silnější je př́má závislost mezi sledovanými proměnnými.

V našem případě je př́má závislost mezi sledovanými proměnnými pozitivní s kladnými hodnotami Spearmanových korelačních koeficienti̊ podle pořadí rozdílů wellness energetických zdrojů <0,776;0,997>. Hodnoty Spearmanových korelačních koeficientů dokazují silnější přímou závislost působení wellness energetických zdrojů v rámci wellness procesu mužů než žen.

\section{Výsledky rámcové analýzy a diskuse}

Pořadí rozdílů wellness energetických zdrojů v rámcích wellness procesu podle pohlaví jsou východiskem k rámování wellness životního stylu vybraných vysokoškoláků. V článku kombinujeme wellness proces s psychologickými a sociálními faktory, které se na rámování životního stylu vybraných vysokoškoláků SU OPF v akademickém roce 2019/2020 podílely. Jak ovlivňuji psychologické faktory jako vnitřni a sociálni faktory jako vnějši životni proměnné rámování wellness životniho stylu vybraných vysokoškolákư? Výsledky rámcové analýzy jsou dopracovány pomocí SWOT analýzy. SWOT jsou počáteční anglická písmena, která v pojetí Sarsbyho (2016) představují čtyři wellness kvadranty. Do wellness kvadrantů řadíme silné stránky (S), slabé stránky (W), př́ležitosti (O) a rizika (T), kde je SWOT zkratkou k pojmenování vnitřních silných a slabých stránek, stejně jako př́ležitostí a rizik vnějšího prostředí. Metodologické sestavování SWOT analýzy podle Gürela a Tatové (2017) předpokládá dodržet čtyřri zásady. První zásadou je vytipovat zásadní faktory v rámci jednotlivých wellness kvadrantů. Druhou zásadou je zásadní faktory umístit do wellness kvadrantů hodnotící SWOT matice. Třetí zásadou je posoudit každý faktor podle jeho významu a důležitosti. Čtvrtou zásadou je navrhnout opatření, která se budou realizovat.

Wellness energetické zdroje v pojetí Stroheckera (2013) lze z hlediska vnitřního a vnějšího působení strukturovat do čtyř wellness kvadranti̊, které srovnávají aktivní a pasivní rámec životního stylu vybraných vysokoškoláků. Dva wellness kvadranty reprezentují aktivní a dva pasivní životní styl a v každém působí jiné wellness energetické zdroje. V aktivním životním stylu působí jako wellness energetické zdroje myšlenky, smysluplnost, vnímání, intimita, pocity, transcendence, které lze považovat za vnitřni psychologické faktory. V pasivním životním stylu působí jako wellness energetické zdroje komunikace, odpovědnost, výživa, dýchání, hra a práce, pohyb, které lze považovat za vnější sociální faktory. (Tabulka 6)

Tabulka 6: Wellness kvadranty rámců životního stylu

\begin{tabular}{|c|c|c|}
\hline Silné stránky (S) & Slabé stránky (W) & \multirow{2}{*}{$\begin{array}{l}\text { Vnitřní wellness } \\
\text { kvadranty aktivního } \\
\text { životního stylu } \\
\text { s psychologickými faktory }\end{array}$} \\
\hline $\begin{array}{l}\text { Myšlenky (S1) } \\
\text { Smysluplnost (S2) } \\
\text { Vnímání (S3) }\end{array}$ & $\begin{array}{l}\text { Intimita (W1) } \\
\text { Pocity (W2) } \\
\text { Transcendence (W3) }\end{array}$ & \\
\hline Př́ležitosti (O) & Rizika (T) & \multirow{2}{*}{$\begin{array}{l}\text { Vnější wellness } \\
\text { kvadranty pasivního } \\
\text { životního stylu } \\
\text { se sociálními faktory }\end{array}$} \\
\hline $\begin{array}{l}\text { Komunikace (O1) } \\
\text { Odpovědnost (O2) } \\
\text { Výživa (O3) }\end{array}$ & $\begin{array}{l}\text { Dýchání (T1) } \\
\text { Hra a práce (T2) } \\
\text { Pohyb (T3) }\end{array}$ & \\
\hline
\end{tabular}

Zdroj: vlastní zpracování 
Ve druhé fázi rámcové analýzy využíváme podle Leibera, Stensakera a Harveyho (2018) pro komparaci wellness energetických zdrojů ve wellness kvadrantech životních stylů hodnotící plus minus maticí. Jedná se o komparaci vzájemných vztahů mezi wellness energetickými zdroji jako psychologickými a sociálními faktory, které ovlivňují životní styl. Zjištěné vzájemné vztahy mezi srovnávanými faktory podle Mandsena (2016) hodnotíme následovně:

- silná oboustranně pozitivní vazba: + +

- silná oboustranné negativní vazba: - -

- slabší pozitivní vazba: +

- slabši negativní vazba: -

- žádný vzájemný vztah: 0

Podle Phadermroda, Crowdera a Willse (2019) jsou výstupem hodnotící plus minus matice součty řádků a sloupců a podle nich stanovené pořadí wellness energetických zdrojů jako zásadních faktorů rámujících wellness životní styl vysokoškoláků jako respondentů. Získáváme tak přehled o působení wellness energetických zdrojů, které lze použít k zpracování rámců wellness životních styli vybraných vysokoškoláků podle pohlaví. Č́íslování wellness energetických zdrojů jako faktorů ovlivňujících rámce životního stylu vybraných vysokoškoláků podle pohlaví vyjadřuje pořadí. Aby vybraní vysokoškoláci mohli zvyšovat kvalitu svého života udržitelným způsobem, zvolili si podle Millera a Fostera (2010) wellness životní styl k dosažení maximální potenciální pohody.

Z hodnotící plus mínus matice wellness životního stylu vybraných žen vychází, že jejich nejsilnější stránkou je vnímání. Podle Jussima (2012) se v každodenní realitě jedná o vnímání mezilidských vztahů. Nejslabší stránkou v případě vybraných žen je transcendence ve smyslu přesahu. Podle Bhaskara (2012) mohou být transcendencí jak každodenní situace, prostor a čas, tak přesah hranic reálné skutečnosti. Nejlepší př́íležitostí pro vybrané ženy zůstává jejich komunikace. Podle Palczewské, DeFranciscové a McGeoughové (2014) lze na komunikaci žen jako na jejich silnou stránku nahlížet se zřetelem k jejich genderové identitě. Největším rizikem, které z plus mínus matice pro vybrané ženy vyplývá, je hra a práce. Ženy podle Gameové a Pringlové (2020) pracují častěji z dủvodu dosažení dokonalosti. V rámci dělby práce však nové technologie často pracovní zátěž žen nesnižují. Nárůst spotřeby naopak způsobuje nárůst pracovních pozic v domácím průmyslu, který není lukrativní. (Tabulka 7)

Tabulka 7: Wellness životní styl vybraných žen

\begin{tabular}{|c|c|c|c|c|c|c|c|c|c|}
\hline & & S1 $\quad-4$ & $\begin{array}{ll}\text { S2 } & -2\end{array}$ & S3 2 & W1 -4 & W2 0 & W3 2 & $\Sigma$ & Pořadí \\
\hline $\mathrm{O} 1$ & 7 & + & + & ++ & + & 0 & ++ & 7 & 1. \\
\hline $\mathrm{O} 2$ & -2 & -- & -- & - & -- & 0 & - & -8 & 4. -6 . \\
\hline $\mathrm{O} 3$ & 1 & - & - & ++ & - & 0 & ++ & 1 & 2. -3 . \\
\hline $\mathrm{T} 1$ & -1 & -- & -- & - & -- & 0 & - & -8 & 4. -6 . \\
\hline $\mathrm{T} 2$ & 1 & - & - & ++ & - & 0 & ++ & 1 & $2 .-3$. \\
\hline $\mathrm{T} 3$ & -8 & -- & -- & - & -- & 0 & - & -8 & 4. -6 . \\
\hline$\Sigma$ & & -8 & -8 & 3 & -8 & 0 & 3 & \multirow{2}{*}{\multicolumn{2}{|c|}{$\begin{array}{l}\text { Hodnotící plus } \\
\text { mínus matice }\end{array}$}} \\
\hline Pořc & & 4. -6 . & 4. -6 . & 1. -2 . & 4. -6 . & 3. & $1 .-2$. & & \\
\hline
\end{tabular}

Zdroj: vlastní zpracování

Plus mínus matice wellness životního stylu vybraných mužů potvrzuje, že jejich nejsilnější stránkou je smysluplnost. S odkazem na smysluplnost Ardell (2009) konstatuje, že wellness je alternativou k závislosti jedince na lécích, nudě a lenosti. K wellness životnímu stylu se však potřebuje jedinec dopracovat, musí aplikovat wellness pravidla jako životní zásady a chápat, že pravidelný fyzický pohyb se ve wellness procesu jako aktivní zapojení v pojetí smysluplné 
aktivity od jedince přímo očekává. Nejslabší stránkou vycházející z plus mínus matice jsou pro vybrané muže jejich pocity, protože působí uzavřeněji než vybrané ženy. Nejlepšími př́ležitostmi jsou komunikace orientovaná na věcné řešení problémů, odpovědnost a výživa. Největším rizikem je málo pohybu jako smysluplné aktivity a mužská orientace na hru a práci. Podle Gameové a Pringlové (2020) se muži nejraději zaměrují na lukrativní pracovní činností. (Tabulka 8)

Tabulka 8: Rámec wellness životního stylu vybraných mužů

\begin{tabular}{|c|c|c|c|c|c|c|c|c|c|}
\hline & & $\begin{array}{ll}\text { S1 } & -7\end{array}$ & $\begin{array}{ll}\text { S2 } & 2\end{array}$ & S3 0 & W1 -8 & W2 1 & W3 2 & $\Sigma$ & Pořadí \\
\hline $\mathrm{O} 1$ & 1 & - & ++ & 0 & - & ++ & ++ & 4 & 1. -5 . \\
\hline $\mathrm{O} 2$ & 5 & - & ++ & 0 & - & ++ & ++ & 4 & 1. -5 . \\
\hline $\mathrm{O} 3$ & 2 & - & ++ & 0 & - & ++ & ++ & 4 & 1. -5 . \\
\hline $\mathrm{T} 1$ & -1 & -- & - & 0 & -- & + & - & -5 & 6. \\
\hline $\mathrm{T} 2$ & 2 & - & ++ & 0 & - & ++ & ++ & 4 & 1. -5 . \\
\hline $\mathrm{T} 3$ & 1 & - & ++ & 0 & - & ++ & ++ & 4 & 1. -5 . \\
\hline$\Sigma$ & & -7 & 9 & 0 & -7 & 11 & 9 & \multirow{2}{*}{\multicolumn{2}{|c|}{$\begin{array}{l}\text { Hodnotící plus } \\
\text { mínus matice }\end{array}$}} \\
\hline Pořa & & $5 .-6$. & $2 .-3$. & 4. & $5 .-6$. & 1. & $2 .-3$. & & \\
\hline
\end{tabular}

Zdroj: vlastní zpracování

\section{Závěr}

Cílem článku bylo zarámovat wellness proces vybraných vysokoškoláků studujících na SU OPF v Karviné v akademickém roce 2019/2020 podle jejich životního stylu. Prezentujeme wellness proces jako wellness rámování pomocí wellness kvadrantů na základě SWOT analýzy k pochopení, že na co vybraní vysokoškoláci myslí a co cítí, ovlivňuje nejen, co říkají a co dělají, ale má dopady také na jejich zdravotní stav a osobní životní styl. (Tabulka 9)

Tabulka 9: Wellness rámování pomocí wellness kvadrantů

\begin{tabular}{|l|l|}
\hline Na co vybraní vysokoškoláci myslí? & Co vybraní vysokoškoláci cítí? \\
\hline To vybraní vysokoškoláci říkají! & To vybraní vysokoškoláci dělají! \\
\hline
\end{tabular}

Zdroj: vlastní zpracování

Wellness proces v článku vnímáme optikou Světové zdravotnické organizace (WHO) s definicí zdravi jako stavu kompletni fyzické, psychické a sociální pohody, která nesestává jen z absence nemoci nebo vady. S odkazem na definici zdraví WHO (1948) se odvoláváme na wellness proces jako na prostředek k milujícímu přijetí sebe sama se zaměřením na část lidského zdraví, kterou můžeme osobním chováním ovlivnit, stejně jako předcházet negativním dopadům civilizačních chorob aktivním životním stylem. Výsledky výzkumné př́ípadové studie vykazují dva rámce wellness životního stylu, které se opírají o rozdílné přístupy vybraných vysokoškoláků $\mathrm{k}$ wellness rámování. Rámce wellness životního stylu podle pohlaví demonstrují rozdílné př́stupy respondentů $\mathrm{k}$ implementaci wellness energetických zdrojů jako vnitřnich psychologických a vnějších sociálních faktorů ve smyslu životních proměnných podle aplikace udržitelných wellness pravidel.

Gnoseologický vztah napovídá, že výběrové podsoubory vysokoškoláků reprezentovaly jeden základní soubor. Z uvedeného vyplývá, že výsledky SWOT analýzy reprezentující rámce jejich wellness životního stylu, jsou zobecněny na př́islušný základní soubor a jsou k nim vztažena doporučení. Závěry článku lze proto formulovat jen pro vysokoškoláky $\mathrm{z}$ výběrových podsouborů a generalizovat rámce wellness životního stylu pouze pro ně. Na druhé straně jsou výsledky výzkumné př́padové studie podle wellness konceptu s energetickými zdroji kombinovanými s rámci aktivního a pasivního životního stylu udržitelné. Dotazníkovými otázkami byl usměrněný pohled vybraných vysokoškoláků na jejich osobní životní styl a na 
přístup k posilování jeho udržitelnosti. Byli motivováni k chápání wellness energetických zdrojů jako součásti životního stylu, což vyústilo k rámování osobního životního stylu a nasměrování přístupu $\mathrm{k}$ wellness procesu. Rámování podle zpětné vazby pomohlo vybraným vysokoškolákům k hodnocení jejich životního stylu, ve kterém se aktuálně nacházejí. Jejich osobní nastavení bylo plynulým a kontinuálním pohybem od jednoho rámce k druhému na ose od pasivních (-) k aktivnějším (+) typům životního stylu.

Proč byl zvolen tento prístup? Pro vybranou skupinu na SU OPF v Karviné fungovaly v akademickém roce 2019/2020 předměty Profesní poradenství, Kariérové poradenství a Komunikační dovednosti, v jejichž rámci byla výzkumná studie provedena. Co jsme od př́stupu očekávali a proč? Výzkumným záměrem bylo formulovat a načasovat otázky v klasickém škálovém dotazníku tak, aby vysokoškoláci z výběrových podsouborů byli schopni vyjádřit úroveň motivační preference $\mathrm{k}$ implementaci wellness energetických zdrojů do rámců wellness procesů. Rozdíly $\mathrm{v}$ pořadí motivačních preferencí identifikují přímou závislost působení wellness energetických zdrojů, která je vyšší v rámcích wellness procesů vybraných mužů než žen. Muži se k aktivnímu životnímu stylu ve formě pohybových aktivit často upínají jako ke spolehlivému ventilu negativní energie nahromaděné vztahovými problémy. Z toho vyplývá jejich wellness životní styl, včetně implementace wellness energetických zdrojů podle udržitelných wellness pravidel jako životních zásad.

\section{Poděkování}

Tento článek vznikl za podpory Ministerstva školství, mládeže a tělovýchovy České republiky v rámci Institucionální podpory dlouhodobého strategického rozvoje Slezské univerzity v Opavě, Obchodně podnikatelské fakulty v Karviné v roce 2021.

\section{Literatura}

[1] ARDELL, D. B., 2009. Prevention, wellness and real wellness. Wellness reports [online]. 11. march 2021 [vid. 11. march 2021]. Dostupné z: http://www.seekwellness.com/wellness/reports/2009-04-08.htm.

[2] BHASKAR, R., 2012. Reflections on Meta Reality. Transcendence, emancipation and everyday life. London: Routledge. ISBN 978-0-415-61903-5.

[3] BRONAS, U. G., M. HANNAN and A. S. LEON, 2019. Lifestyle management and Prevention of Hypertension. In: J. M. RIPPE, eds. Medicine Lifestyle. 3th ed. London: CRC Press, pp. 65-74. ISBN 9781138708846.

[4] GAME, A. and R. PRINGLE, 2020. Gender at Work. New York: Routledge. ISBN 086861-261-8.

[5] GIDDENS, A., 2013. Social Theory and Modern Sociology. Cambridge: John Wiley \& Sons. ISBN 978-0-7456-6664-8.

[6] GÜREL, E. and M. TAT, 2017. SWOT analysis. A Theoretical Review. Journal of International Social Research. 51(10), 994-1006. ISSN 1307-9581.

[7] HANCOCK, G. R., L. M. STAPLETON and R. O. MUELLER. The Reviewer's Guide to Quantitative Methods in the Social Sciences. 2nd ed. New York: Routledge. ISBN 9781315755649.

[8] Informační systém Slezské univerzity. [online]. 27. srpen 2020. [vid. 27. srpen 2020]. Dostupné z: https://www.slu.cz/slu/cz/issu 
[9] INFO@AION.CZ, AION CS. 189/1948 Sb. Zřízení a Ústava Světové zdravotnické organisace a o Protokolu o Mezinárodním úřadu zdravotnictví. Zákony pro lidi [online]. 10. květen 2020 [vid. 10. květen 2020]. Dostupné z: https://www.zakonyprolidi.cz/cs/1948-189/zneni-19480804

[10] JUSSIM, L., 2012. Social Perception and Social Reality. Oxford: University Press. ISBN 978-0-19-536660-0.

[11] KUBÁTOVÁ, H., 2016. Ways of Life in the Late Modernity. Olomouc: Palacký University Philosophical Faculty. ISBN 978-80-244-3450-6.

[12] LEIBER, T., B. STENSAKER and L. C. HARVEY, 2018. Bridging theory and practice of impact evaluation of quality management in higher education institutions: a SWOT analysis. European Journal of Higher Education, 8(5), 351-365. ISSN 2156-8243.

[13] MAJOR, H. L., 2018. Framing the Social Determinants of Health: A Combined Frames Approach. In: D'ANGELO, P., Doing News Framing Analysis II.: Empirical and Theoretical Perspectivenes. 2nd ed. New York: Reutledge, p. 320-342. ISBN 978-1-13818855-6.

[14] MANDSEN, D. Q., 2016. SWOT Analysis: A Management Fashion Perspective. International Journal of Business Research, 16(1), 39-56. ISSN 2029-9338.

[15] MILLER, G. and L. T. FOSTER, 2010. Critical synthesis of wellness literature. University of Victoria [online]. 11. march 2021 [vid. 11. march 2021]. Dostupné z: http://www.geog.uvic.ca/wellness/

[16] PALCZEWSKI, C. H., V. P. De FRANCISCO and D. D. Mc GEOUGH, 2014. Gender in Communication. A critical Introduction. 2nd ed. London: SAGE Publications, ISBN 9781452220093.

[17] PHADERMROD, B., R. M. CROWDER and G. B. WILLS, 2019. ImportancePerformance Analysis based SWOT analysis. International Journal of Information Management, 44(9), 194-203. ISSN 0268-4012.

[18] SARSBY, A., 2016. SWOT analysis. A guide to SWOT for business studies students. London: Spectaris. ISBN 978-0-9932504-2-2.

[19] STROHECKER, J., 2013. 12 dimensions of wellness. An invitation to Wellnes inventory certification training [online]. 21. april 2020. [vid. 21. april 2020]. Dostupné z: http://www.wellpeople.com/Wellness_Dimensions.aspx\#Sec1

[20] TRAVIS, J. W. and R. S. RYAN, 2004. The wellness Workbook. How to achieve enduring health and vitality. 3th ed. Berkeley: Celestial Arts [online]. 16. november. 2021 [vid. 16. november 2021]. Dostupné z: http://www.thewellspring.com/flex/personalwellness/350/introduction-towellness.cfm. 